\title{
Chemical Composition, Minerals and Antioxidants of the Heart of Date Palm from Three Saudi Cultivars
}

\author{
Dina M. Trabzuni, Saif Eldien B. Ahmed, Hamza M. Abu-Tarboush* \\ Department of Food Science and Nutrition, College of Food and Agriculture Sciences, King Saud University, \\ Riyadh, KSA \\ Email: dina.trabzuni@gmail.com, saif195561@yahoo.com, ${ }^{*}$ tarboush@ksu.edu.sa
}

Received 27 May 2014; revised 3 July 2014; accepted 16 July 2014

Copyright (C) 2014 by authors and Scientific Research Publishing Inc.

This work is licensed under the Creative Commons Attribution International License (CC BY).

http://creativecommons.org/licenses/by/4.0/

(c) (i) Open Access

\begin{abstract}
The aim of this study was to determine the chemical composition, minerals and antioxidants of heart of date palm from three Saudi cultivars. Moisture (ranged from $80.44 \%-82.82 \%$ ) was the predominant component in the heart date palm. Sukkari cultivar had the highest protein (5.27\%) and ash (7.9\%) compared to the other two cultivars. Fat was low in the three cultivars. Sucrose was the predominant sugar in the heart date palm and ranged from $7.65 \%-20.25 \%$. Potassium was the predominant mineral in the heart date palm and was significantly $(p<0.05)$ higher in Sukkari and Solleg compared to the Naboat Saif cultivar. Sulfur and chloride were next to potassium in abundance in the three heart date palm cultivars. Total phenols and flavonoids were higher in Solleg compared to the other two cultivars. IC $_{50}$ for Solleg, Sukkari and Naboat Saif were $0.12,0.13$ and $0.29 \mathrm{mg} / \mathrm{ml}$, respectively. The results of the present study may highlight the potential importance of heart of date palm as a product rich in essential minerals and antioxidants. Future researches are needed to explore other characteristics of heart of date palm which could be considered for human nutrition.
\end{abstract}

\section{Keywords}

Heart of Date Palm, Composition, Minerals, Antioxidants

\section{Introduction}

The palm family (Arecaceae) is comprised of 183 genera and over 2400 species. The five major palm species are nut palm, peach palm, coconut palm, oil palm and date palm [1]. Date palm tree, Phoenix dactylifera L., is an important plantation crop for many countries extending from North Africa to the Middle East including many states of the Arabian Gulf cooperation countries [2]. Date palm is an important fruit crop in the Kingdom of *Corresponding author.

How to cite this paper: Trabzuni, D.M., Ahmed, S.E.B. and Abu-Tarboush, H.M. (2014) Chemical Composition, Minerals and Antioxidants of the Heart of Date Palm from Three Saudi Cultivars. Food and Nutrition Sciences, 5, 1379-1386. 
Saudi Arabia and it has more than 23 million date palm trees and over 320 varieties with annual earning of over 500 million USD [3]. Chemical composition, phenolic composition and antioxidant capacities of date fruits were reported in many studies [2] [4]-[6].

Heart-of-palm is extracted from several palm genera and species [7]. The heart of palm is composed of the apical meristem of the palm plus part of the young or immature leaves emerging from the meristem. This edible meristem is frequently consumed in salads, soups and other gourmet dishes [8]. Saudis consume this product in its fresh form immediately after its extraction from the tree. Pollack et al. [9] considered palm heart as a nontimber forest product that could add to the economy of tropical countries. Ecuador is the biggest world exporter of palm heart followed by Costa Rica and Brazil [10]. Hearts of palm are relatively rich in protein $(2.81 \%-2.27 \%$ in fresh weight) and contain 17 amino acids. All the essential amino acids present in heart of palm. Hearts of palm are also excellent source of dietary fiber. They are moderate source of minerals such as $\mathrm{Ca}, \mathrm{Fe}, \mathrm{K}, \mathrm{Na}, \mathrm{P}$, and Zn. However, they are low in fat and sugars [8]. The nutritional value of heart of palm (extracted from an Iranian date palm variety) was also investigated by Movahed et al. [11]. They stated that the sample contains unsaturated fatty acids, minerals ( $\mathrm{Zn}, \mathrm{Fe}, \mathrm{Mg}, \mathrm{P}, \mathrm{Mn}, \mathrm{Ca}, \mathrm{Cu}, \mathrm{Na}, \mathrm{K}$ and $\mathrm{Se}$ ) and crude fiber in fair amounts. Shimizu et al. [10] investigated the phenolic profile and polypherol oxidase activity in heart of palm samples extracted from three commercial species.

The present work may be the first in studying chemical and nutritional properties of heart of date palm of Saudi origin. Heart of palm or Al-Guomar, as locally called, has no economic value compared to date fruits. The data obtained from analyses in this study may help in expanding the utilization of this date palm product.

\section{Material and Methods}

\subsection{Preparation of Heart of Palm Samples}

Samples consisting of stems and leaves of three Saudi date palm varieties (Sokari, Nabout Saif, and Soulag) were obtained from Agricultural Experimental Station at Derab in Riyadh, King Saud University. An experienced staff affiliated to plant production department (Faculty of Food and Agriculture Sciences) was involved in peeling of date palm heart (Al-Goumar) samples, considering minimizing losses in heart of date palm tissue. Heart of palm samples were quickly freed from other plant debris then freeze dried. The dried material was milled to pass 60 mesh sieves and the flour was stored in air tight container and kept at $4^{\circ} \mathrm{C}$ until further analysis.

\subsection{Chemical Composition}

Moisture, ash, lipid and crude protein contents were determined by methods of standard Association of Official Analytical Chemists [12]. Sugars (glucose, fructose, sucrose) were extracted from heart of date palm samples following Lane and Enon method [12]. Sugar analysis was carried out using Shimadzu HPLC-Lc 10AB, detector RID-10A. Acetonitrile (80\%) and water (20\%) were used as mobile phase. Data acquisition was performed with the Shimadzu LC-Solution Software.

\subsection{Mineral Determination}

The instruction of the instrumental (ICP-MS) manual was followed for sample preparation and calibration.

\subsubsection{Reagents}

Nitric acid $\left(\mathrm{HNO}_{3}\right)(69 \% \mathrm{v} / \mathrm{v})$, super purity grade from Romil, England, hydrochloric acid $(\mathrm{HCl})(37 \% \mathrm{v} / \mathrm{v})$ and hydrofluoric acid (HF) (40\% v/v) were supra-pure from Merck Germany. High purity water obtained from Millipore Milli-Q water purification system was used throughout the work.

\subsubsection{Sample Preparation}

Freeze-dried date palm heart samples were ground then sieved to pass through $200 \mathrm{~mm}$ sieve and transferred to plastics bags. Samples were prepared by accurately weighing a round $200 \mathrm{mg}$ of samples into a dry and clean Teflon digestion beaker, $2 \mathrm{ml}$ of $\mathrm{HNO}_{3}, 6 \mathrm{ml} \mathrm{HCl}$ and $2 \mathrm{ml} \mathrm{HF}$ were added to the Teflon beaker. Samples were digested on the hot plate at $120^{\circ} \mathrm{C}-150^{\circ} \mathrm{C}$ for approximately 40 minutes. The resulting digest was not clear, so it was filtered through what man filtered paper No. 42. The filtered digest was transferred to a $50 \mathrm{ml}$ plastic volumetric flask and made up to mark using deionized water. A blank digest was carried out in the same way. 


\subsubsection{Instrumentation}

The analytical determination of minerals was carried out by ICP-MS (Inductively Coupled Plasma-Mass Spectrometer): ELAN 9000 (Perkin Elmer Sciex Instrument, Concord, Ontario, Canada). The operation conditions of the instruments used was as follows: RF power: $1250 \mathrm{~W}$; nebulizer gas flow: $0.92 \mathrm{~L} / \mathrm{min}$; lens voltage: $9.25 \mathrm{~V}$; analog stage voltage: $-1762.5 \mathrm{~V}$; pulse stage voltage: $1050 \mathrm{~V}$; number of replicates: 3; reading/replicates: 20; scan mode: peak hopping dwell time: $40 \mathrm{~ms}$, and integration: $1200 \mathrm{~ms}$.

\subsubsection{Calibration}

The ICP-MS calibration was carried out by external calibration with the blank solution and three working standard solutions (10, 20 and $30 \mu \mathrm{g} / \mathrm{L}$ ), starting from a $1000 \mathrm{mg} / \mathrm{L}$ single standard solutions for ICP-MS (Aristar grade, BDH laboratory supplies, England) for the trace elements.

\subsection{Antioxidants Determination}

\subsubsection{Reagents}

Folin-Cioalteau's phenolic reagent, 2,2-dyphenyl-picrylhydrazyl (DPPH), and Gallic acid obtained from Sigma. All other reagents were of analytical grade.

\subsubsection{Preparation of the Extracts}

A powder of each material $(10 \mathrm{~g})$ was extracted by $100 \mathrm{ml}$ of $60 \%$ ethanol with continuous shaking at $30^{\circ} \mathrm{C}$ for $24 \mathrm{~h}$. The extracts were filtered through what man No. 1 filter paper and the liquid portions were analyzed for their phenolic, falvonoids and their antioxidants activity. Samples were analyzed in triplicate.

\subsubsection{Determination of Plant Extract Yield}

The yield dried date palm heart extract based on dry weight basis was calculated on the following equation. Yield g/100 gram plant material $=(\mathrm{W} 1 \times 100) / \mathrm{W} 2$

W1 and W2 were the weight of extract after the solvent evaporation and the weight of dry plant tissue material, respectively.

\subsubsection{Total Phenol Content Determination}

The polyphenol content was quantified by the Folin-Ciocalteau phenol reagent according to the protocol of Xu and Chang [13]. The method is based on the colored reaction of phenolics with the reagent. Folin-Ciocalteau reagent is reduced to a blue colored oxide at $\mathrm{pH} 9.0$ upon the reaction with phenols. Intensity of the resulting color was measured in a spectrophotometer at $765 \mathrm{~nm}$. Aliquots of test samples $(50 \mu \mathrm{l}, 20 \mathrm{mg}$ sample $/ \mathrm{ml} 60 \%$ ethanol) were mixed with $3.0 \mathrm{ml}$ distilled water, $750 \mu \mathrm{l} 7 \% \mathrm{Na}_{2} \mathrm{CO}_{3}$, and $0.5 \mathrm{ml}$ Folin-Ciocalteau reagent. The absorbance was measured at $765 \mathrm{~nm}$ after $30 \mathrm{~min}$ incubation at room temperature. The standard curve (Figure 1) was prepared using known concentrations of Gallic acid (GAE). The total phenol content in the test samples was calculated from the Gallic acid standard curve and expressed as mg GAE/100mg sample.

\subsubsection{Determination of Total Flavonoid Content}

Colorimetric aluminum chloride method was used for flavonoid determination using a method by Xu and Chang [13]. Aliquots of extract were taken and the volume made to $2 \mathrm{ml}$ with distilled water and then mixed with $75 \mu \mathrm{l}$ of $5 \% \mathrm{NaNO}_{2}$. After $6 \mathrm{~min}, 150 \mu \mathrm{AlCl}_{3}(10 \%)$ solution was added and allowed to stand for 5 min before adding $0.5 \mathrm{ml}$ of $1.0 \mathrm{M} \mathrm{NaOH}$ and $2.5 \mathrm{ml}$ distilled water. The solution was mixed and the absorbance was measured at $510 \mathrm{~nm}$. A standard calibration curve was prepared using known concentrations of quercetin (QE). The total flavonoid in the test samples were calculated from the standard plot and expressed as mg QE/100mg sample.

\subsubsection{DPPH Radical-Scavenging Activity}

The DPPH assay method is based on the reduction of 2,2-diphenyl-1-picryl hydrzyl radical (DPPH), a stable free radical. The effect of phenolic compounds on the DPPH radical was used for determination of antioxidant activity of the extracts. When DPPH reacts with an antioxidant compound it can donate hydrogen, it is reduced and the color changes from deep violet to light yellow.

The ability of the samples scavenge DPPH radicals was determined according to the method of Xu and Chang [13], with some modifications. DPPH (0.1 mM) radical solution in 95\% ethanol was prepared. DPPH stock so- 


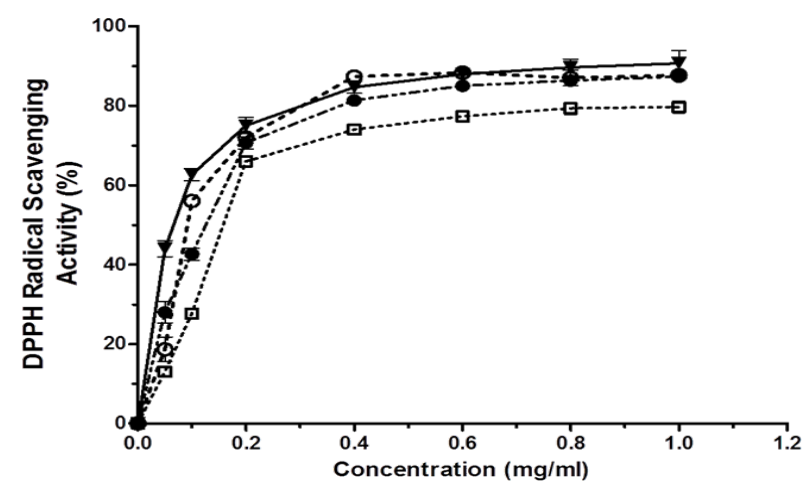

Figure 1. DPPH free radical scavenging activity of date palm heart ethanolic extracts (sollejo, nabot saif $\bullet$, sukkari $\square$, and standard ascorbic acid $\mathbf{\nabla}$ ).

lution ( $1 \mathrm{ml}$ ) was added to various concentrations $(0.01-1 \mathrm{mg} / \mathrm{ml}$ in $60 \%$ ethanol). The control was prepared as above without any extract. The reaction mixture was allowed to stand in dark for $30 \mathrm{~min}$ at room temperature and the discoloration of DPPH was measured against blank at $517 \mathrm{~nm}$. The radical scavenging was calculated using the following equation:

$$
\text { Scavenging effect }(\%)=\left(1-\frac{\text { Abs.Sample }(517 \mathrm{~nm})}{\text { Abs.Control }(517 \mathrm{~nm})}\right) \times 100
$$

The assay was carried out in triplicate and the results were expressed as mean values \pm standard deviation.

\subsection{Statistical Analysis}

All analyses were carried out in triplicate and data were expressed as mean \pm standard deviation. Duncan's test for multiple mean comparisons was performed to determine differences $(\mathrm{P} \leq 0.05)$ between means. Results were processed using SAS statistical programs.

\section{Results and Discussion}

\subsection{Chemical Composition}

Chemical composition of date palm heart samples is shown in Table 1. Values of protein, fat, ash and carbohydrates were presented in wet and dry weight basis. Moisture is the predominant component in the fresh samples, ranging between $80.44 \%$ - 82.82\%. Heart palm of Sukkari contained the highest amount of protein (2.57\%) in wet weight basis. Movahed et al. [11] reported low value of protein (1.06\%) for heart of date palm of Iranian variety. Fat contents (dry weight basis) for Sukkari, Sollag and Naboat Saif were higher than that reported by Simias et al. [14] in King Palm flour (0.91\%). One unique feature in the composition of the three samples (Table 1) is their high content in ash and carbohydrates. Ash contents expressed in dry weight basis of Sukkari, Sollag and Naboat Saif were $42.82 \%, 42.90 \%$ and $37.88 \%$, respectively. Chemical composition of date flesh and date by-products for Omani varieties was reported by Al-Faris et al. [4]. They stated that ash content (in dry basis) for date flesh, press cake and seed were $1.65 \%-2.2 \%, 1.88 \%-2.68 \%$ and $0.94 \%-1.21 \%$, respectively. Ash

Table 1. Chemical composition (\%) of Al-Goamar samples (\%) in wet weight basis.

\begin{tabular}{cccccc}
\hline Sample & Moisture & Protein & Fat & Ash & Carbohydrate $^{* *}$ \\
\hline \multirow{2}{*}{ Sukkari } & $81.55^{*} \pm 0.27^{\mathrm{b}}$ & $5.27 \pm 0.003^{\mathrm{a}}$ & $0.32 \pm 0.05^{\mathrm{a}}$ & $7.90 \pm 0.005^{\mathrm{a}}$ & $(42.82)$ \\
& & $(13.93)^{* * *}$ & $(1.73)$ & 7.66 \\
Solleg & $82.82 \pm 0.07^{\mathrm{a}}$ & $1.80 \pm 0.09^{\mathrm{b}}$ & $0.32 \pm 0.04^{\mathrm{a}}$ & $7.38 \pm 0.04^{\mathrm{b}}$ & $(41.52)$ \\
& & $(10.48)$ & $(1.86)$ & $(42.90)$ & 7.68 \\
\multirow{2}{*}{ Naboat Saif } & $80.44 \pm 0.41^{\mathrm{c}}$ & $1.86 \pm 0.41^{\mathrm{b}}$ & $0.32 \pm 0.06^{\mathrm{a}}$ & $7.41 \pm 0.07^{\mathrm{b}}$ & $(44.70)$ \\
& & $(9.51)$ & $(1.64)$ & $(37.88)$ & 9.97 \\
\end{tabular}

${ }^{*}$ Mean \pm Standard Deviation $(\mathrm{N}=3)$. Means with different letters in the same column are significantly different $(\mathrm{P} \leq 0.05) .{ }^{* *}$ Carbohydrates calculated by difference. ${ }^{* * * *}$ Protein, fat ash and carbohydrates values between brackets are calculated in dry weight basis. 
content reflects the mineral composition of the product. Leterme et al. [15] found high correlations $(\mathrm{P} \leq 0.001)$ between total ash and concentrations of most macro- and micro-minerals they analyzed in some fruits and unconventional foods. The carbohydrates component is high $(41.52 \%-50.92 \%)$ for the three samples in dry weight basis. Carbohydrates of heart of palm composed mainly of fiber [11]. Consumption of rich fiber foods has been most extensively studied regarding health benefits [16]. Concentrations of sugars (glucose, fructose, sucrose) were determined for the three samples (Table 2). Concentrations of glucose and fructose in Naboat Saif and Sukkari were lower than that reported by Saleh et al. [2] for these sugars in date palm fruits, also Simas et al. [14] reported high glucose content (32.1\%) in king palm flour.

\subsection{Mineral Composition}

The composition of minerals of date palm heart samples is shown in Table $3 . \mathrm{Na}, \mathrm{K}, \mathrm{Mg}, \mathrm{Ca}, \mathrm{P}, \mathrm{Cl}$ and $\mathrm{S}$ contents are high compared to other minerals for the three samples. These seven elements called Macro-minerals are distinguished from the micro-minerals by their occurrence in the body, as they required in amounts greater than $100 \mathrm{mg}$ per day [17]. K presented the highest content in the three samples. Leterme et al. [15] stated that K presented an average of 32\% of the total mineral content of samples investigated. $\mathrm{Cl}$, S and Ca come second to $\mathrm{K}$ in abundance in heart of date palm samples. All the mentioned macro-minerals have vital physiological and biochemical functions in human body. The four essential micro-minerals Fe, I, Se and $\mathrm{Zn}$ are present in the three samples in varying amounts. Compared to King palm flour mineral composition [14], only Zn and Se are found in fair amounts. Cu content of the three samples $(20.31-30.00 \mu \mathrm{g} / \mathrm{g})$ considered to be fair compared to other plant-based foods [15]. Se is another mineral found in the three samples (Table 3) in amounts comparable to other dietary sources. The greatest biological significance of selenium in the organism is associated with its occurrence in active sites of many enzymes and proteins [18]. Some of the micro-minerals (B, Si, Sn and $\mathrm{Sr}$ ) are found in heart of date palm samples (Table 3) in varying amount, e.g. Sr in Naboat Saif was higher than the other two samples, whereas Si was higher in Solleg compared to the other two cultivars. B, Si, Sn and Sr are found in humans as ultra trace minerals.

Other minerals, may be described as heavy metals ( $\mathrm{Pb}, \mathrm{Cd}, \mathrm{Al}$ and $\mathrm{Sb})$ and rare metals ( $\mathrm{Rb}, \mathrm{Cs}, \mathrm{La}$ and $\mathrm{In}$ ) were found in the samples investigated in varying amounts. Sb in Naboat Saif was higher compared to the other two samples. For the micro-minerals described as heavy or rare metals very little is known about the human needs or their roles in animal and human nutrition.

The diverse mineral composition of heart of date palm may be explained by the bioaccumulation capabilities of date palm tree to absorb minerals from the soil and accumulates these minerals in its tissues like other plant species such as mushrooms [19] [20]. Aldjain et al. [21] determined the concentration of lead (Pb) and cadmium (Cd) in washing residues and in the tissues of fruits of date palm growing in 14 sites of Riyadh. They stated that humans are likely to be exposed to heavy metal contamination from the dust that adheres to edible plants than from bioaccumulation.

\subsection{Total Phenols, Total Flavonoids and Antioxidant Activity}

\subsubsection{Extraction Yield}

The extraction yields of the three date palm heart samples using ethanol (60\%) were 13.40\%, 9.93\% and 9.12\% for Solleg Sukkari and Naboat Saif, respectively. Extraction yield is the percentage of weight of extract (after solvent evaporation) to the weight of total dry sample. Quantitatively extraction yield may indicate the amount of polyphenols present in the sample. Al-Farsi et al. [22] reported that the extraction yield (g/100g of date seed) of phenolic concentrate using water and acetone was 6.51 and 18.1, respectively. They reported that acetone had also high extraction efficiency.

\subsubsection{Total Phenols and Flavonoids:}

Total phenolic content (TPC) and total flavonoid content (TFC) of date palm heart samples are presented in-Table 4. Solleg had higher significant $(\mathrm{P} \leq 0.05)$ TPC and TFC compared to the other two samples, while Na boat Saif come next for both components. The beneficial effects derived from phenolic compounds have been attributed to their antioxidant activity [23] and studies have suggested the role of phenolic compounds as the major sources natural antioxidants in foods of plant origin [24]. The results of TPC (Table 4) were lower than TFC of methanol extract of king palm flour (127 mg/100g) as reported by Simas et al. [14] and lower than total phenolics $(73 \mathrm{mg} / \mathrm{g}$ ) in fruit pulp of asaì tree (a primary source of heart-of-palm in Brazil) as found by Kang et 
Table 2. Sugar content of heart of date palm samples (g/100g).

\begin{tabular}{cccc}
\hline Sample (Freeze-Dried) & Fructose & Glucose & Sucrose \\
\hline Naboat Saif & $6.50^{\mathrm{a}} \pm 0.186^{*}$ & $6.76^{\mathrm{a}} \pm 0.736$ & $7.65^{\mathrm{c}} \pm 0.520$ \\
Sollag & $\mathrm{ND}^{* *}$ & $\mathrm{ND}$ & $20.25^{\mathrm{a}} \pm 0.245$ \\
Sukkari & $4.77^{\mathrm{b}} \pm 0.072$ & $5.58^{\mathrm{a}} \pm 0.310$ & $8.90^{\mathrm{b}} \pm 0.440$ \\
\hline
\end{tabular}

${ }^{*}$ Mean \pm Standard Deviation $(\mathrm{N}=3)$, means with different letters in the same column are significantly different $(\mathrm{P} \leq 0.05)$. ND ${ }^{* *}=$ not detected.

Table 3. Mineral composition of date palm heart sample ( $\mu \mathrm{g} / \mathrm{g})$.

\begin{tabular}{|c|c|c|c|}
\hline Mineral & Naboat Saif & Solleg & Sukkari \\
\hline Sodium (Na) & $690.00 \pm 1.54^{\mathrm{a}}$ & $58.00 \pm 1.78^{\mathrm{c}}$ & $141.00 \pm 4.82^{\mathrm{b}}$ \\
\hline Potassium (K) & $8281.00 \pm 471.2^{\mathrm{b}}$ & $9168.00 \pm 302.4^{\mathrm{a}}$ & $11769.00 \pm 174.14^{\mathrm{a}}$ \\
\hline Magnesium (Mg) & $640.00 \pm 8.38^{\mathrm{a}}$ & $691.00 \pm 23.97^{\mathrm{a}}$ & $649.00 \pm 6.01^{\mathrm{a}}$ \\
\hline Calcium (Ca) & $12.00 \pm 10.82^{\mathrm{a}}$ & $899.00 \pm 26.72^{\mathrm{b}}$ & $819.00 \pm 13.86^{c}$ \\
\hline Phosphorus (P) & $622.00 \pm 9.42^{\mathrm{a}}$ & $583.00 \pm 26.72^{\mathrm{b}}$ & $598.00 \pm 1.89^{\mathrm{a}}$ \\
\hline Aluminum (Al) & $1.67 \pm 0.03^{\mathrm{b}}$ & $1.52 \pm 0.02^{\mathrm{c}}$ & $2.54 \pm 0.04^{\mathrm{a}}$ \\
\hline Iron $(\mathrm{Fe})$ & $2.20 \pm 0.02^{\mathrm{a}}$ & $1.95 \pm 0.02^{\mathrm{b}}$ & $2.10 \pm 0.01^{\mathrm{c}}$ \\
\hline Copper (Cu) & $23.00 \pm 0.69^{\mathrm{b}}$ & $30.00 \pm 0.40^{\mathrm{a}}$ & $20.31 \pm 0.39^{\mathrm{b}}$ \\
\hline Sulfur (S) & $6196.00 \pm 22.67^{\mathrm{a}}$ & $5322.00 \pm 81.04^{\mathrm{b}}$ & $5453.00 \pm 13.78^{\mathrm{b}}$ \\
\hline Chloride (Cl) & $4826.00 \pm 44.70^{\mathrm{b}}$ & $6371.00 \pm 459.00^{\mathrm{a}}$ & $6466.00 \pm 27.70^{\mathrm{a}}$ \\
\hline Iodine (I) & Trace & Trace & Trace \\
\hline Magnesium (Mn) & $2.59 \pm 0 / 03^{b}$ & $2.92 \pm 0.06^{\mathrm{a}}$ & $3.02 \pm 0.04^{\mathrm{a}}$ \\
\hline Selenium (Se) & $3.34 \pm 0.03^{c}$ & $3.91 \pm 0.05^{\mathrm{b}}$ & $5.12 \pm 0.03^{\mathrm{a}}$ \\
\hline Boron (B) & $1.92 \pm 0.03^{\mathrm{b}}$ & $2.33 \pm 0.10^{\mathrm{a}}$ & $2.47 \pm 0.03^{\mathrm{a}}$ \\
\hline Silicon (Si) & $19.00 \pm 019^{c}$ & $36.0 \pm 0.87^{\mathrm{a}}$ & $29.00 \pm 0.22^{\mathrm{b}}$ \\
\hline Lead $(\mathrm{Pb})$ & $0.74 \pm 0.02^{\mathrm{c}}$ & $12.0 \pm 0.05^{\mathrm{a}}$ & $2.26 \pm 0.14^{\mathrm{b}}$ \\
\hline Cadmium (Cd) & $5.87 \pm 0.09^{\mathrm{a}}$ & $6.11 \pm 0.08^{\mathrm{a}}$ & $3.95 \pm 0.33^{\mathrm{b}}$ \\
\hline Antimony (Sb) & $370.00 \pm 0.37^{\mathrm{a}}$ & $100.00 \pm 1.34^{\mathrm{c}}$ & $160.00 \pm 2.49^{\mathrm{b}}$ \\
\hline Tin (Sn) & $3.24 \pm 0.0 .24^{\mathrm{b}}$ & $4.54 \pm 0.17^{\mathrm{a}}$ & $4.95 \pm 0.28^{\mathrm{c}}$ \\
\hline Zinc (Zn) & $19.80 \pm 0.11^{\mathrm{a}}$ & $17.64 \pm 0.53^{\mathrm{b}}$ & $14.17 \pm 0.08^{\mathrm{c}}$ \\
\hline Rubidium (Rb) & $38.00 \pm 0.17^{\mathrm{a}}$ & $10.00 \pm 0.05^{\mathrm{c}}$ & $15.00 \pm 0.19^{\mathrm{b}}$ \\
\hline Cesium (Cs) & $2.00 \pm 0.02^{\mathrm{a}}$ & $1.90 \pm 0.02^{\mathrm{b}}$ & $2.00 \pm 0.04^{\mathrm{a}}$ \\
\hline Lanthanum (La) & $0.60 \pm 0.01^{\mathrm{b}}$ & $1.30 \pm 0.01^{\mathrm{b}}$ & $7.60 \pm 0.48^{\mathrm{a}}$ \\
\hline Strontium (Sr) & $58.00 \pm 0.34^{\mathrm{a}}$ & $19.00 \pm 0.34^{\mathrm{c}}$ & $26.00 \pm 0.08^{\mathrm{b}}$ \\
\hline Indium (In) & $232.00 \pm 0.04^{\mathrm{a}}$ & $64.00 \pm 0.99^{c}$ & $100.00 \pm 0.92^{\mathrm{b}}$ \\
\hline Chromium (Cr) & $1.98 \pm 0.01^{\mathrm{a}}$ & $1.83 \pm 0.03^{\mathrm{b}}$ & $1.93 \pm 0.01^{\mathrm{ab}}$ \\
\hline
\end{tabular}

Table 4. Total phenolic content (TPC) and total flavonoid (TFC) content of date palm heart extract fractions.

\begin{tabular}{ccc}
\hline Date sample (freeze-dried) & TP (mg GAE/100g extract) & TFC (mg QE/100g extract) \\
\hline Solleg & ${ }^{*} 56.05 \pm 0.60^{\mathrm{a}}$ & $6.82 \pm 0.20^{\mathrm{a}}$ \\
Sukkari & $25.90 \pm 0.43^{\mathrm{c}}$ & $4.86 \pm 0.07^{\mathrm{c}}$ \\
Naboat Saif & $41.44 \pm 0.72^{\mathrm{b}}$ & $5.24 \pm 0.06^{\mathrm{b}}$ \\
\hline
\end{tabular}

${ }^{*}$ Mean \pm Standard Deviation $(\mathrm{N}=3)$, means with different letters in the same column are significantly different $(\mathrm{P} \leq 0.05)$. GAE $=$ Gallic acid. $\mathrm{QE}=$ Quercetin.

al. [25]. Simas et al. [14] determined total polyphenol content in king palm flour. They found that both methanolic and aqueous extracts contained total polyphenol in amounts higher than other plant samples they analyzed.

They reported that beneficial effects derived from phenolic compound have been attributed to their antioxidant activity. They further stated that antioxidant activity of the extracts cannot be predicted only by total polyphenol content. The values of TFC of the three samples (Table 4) were much lower than the total flavonoid content of dry date fruit of Iranian origin $(81.79 \mathrm{mg} / 100 \mathrm{~g})$ as reported by Biglari et al. [26].

\subsubsection{Antioxidant Activity}

The ability of heart of date palm samples to scavenge DPPH radicals was determined and the results are show- 
nin Figure 1. Because DPPH radical is very sensitive to active ingredients of low concentration and can accommodate a large number of samples in a very short time, this procedure is often used for measuring radical scavenging activity of different plant extracts [27]. Referring to Figure 1; concentration of $1 \mathrm{mg} / \mathrm{ml}$ corresponds approximately to scavenging activities of $91 \%, 88 \%, 80 \%$ and $88 \%$ for ascorbic acid (Standard), for Solleg Naboat Saif and Sukkari, respectively. Benmeddour et al. [6] reported that DPPH scavenging capacity of 10 Algerian date (fruit) cultivars ranged between $52.2 \%$ and $86.0 \%$. In the same context, Mansouri et al. [28] stated that DPPH radical scavenging activity of date fruit was highly correlated with the phenolics content $\left(\mathrm{r}^{2}=0.99\right)$. In this study, DPPH residual scavenging activity (\%) was plotted against the sample extract concentration and a linear regression curve was established in order to calculate $\mathrm{IC}_{50}$, which is the amount of sample required to decrease the absorbance of DPPH free radical by $50 \%$. IC $_{50}$ values of ascorbic acid for Solleg, Sukkari and Naboat Saif were $0.12,0.22,0.23$ and $0.29 \mathrm{mg} / \mathrm{ml}$, respectively. Ascorbic acid has the lowest $\mathrm{IC}_{50}$ value compared to the three samples. In DPPH assay, the lower the $\mathrm{IC}_{50}$ the better it is ability to scavenge the radicals [29]. $\mathrm{IC}_{50}$ value of methanol extract of seeds of Nigella sativa (blackcumin) was found to be 168.8 compared to $8.6 \mu \mathrm{g} / \mathrm{ml}$ for ascorbic acid as standard [30].

\section{Conclusion}

Comparatively minor attention has been given to date palm products other than the fruits. Utilization of all parts of the date palm may offer socio-economic benefits to date farmers and other sectors. The results of the present study may highlight the potential importance of heart of date palm as a product rich in essential minerals and antioxidants. Future researches are needed to explore other characteristics of heart of date palm which could be considered for human nutrition.

\section{Acknowledgements}

Authors would like to thank The Agriculture Research Centre at the College of Food and Agriculture Science at King Saud University for the financial support of this research. Thanks also extended to Professor Rashid Alobeed and Professor Saeed Saad Soliman for their help in providing date palm cultivars and extracting the heart of date palm.

\section{References}

[1] Johnson, D.V. (2012) Enhancement of Date Palm as a Source of Multiple Products: Examples from Other Industrialized Palms. Emirates Journal of Food and Agriculture, 24, 408-414.

[2] Saleh, E.A., Tawfik, M.S. and Abu-Tarboush, H.M. (2011) Phenolic Contents and Antioxidant Activity of Various Date Palm (phoenix dactylifera L.) Fruits from Saudi Arabia. Food and Nutrition Sciences, 2, 1134-1141. http://dx.doi.org/10.4236/fns.2011.210152

[3] Al-Khalifa, N.S. (2012) First Arab Palm Conference on the Development of Date Palm and Dates Sector in the Arab World. Emirates Journal of Food and Agriculture, 21, Convener Note.

[4] Al-Farsi, M.A., Alasalvar, C., Al-Abid, M., Al-Shoaily, K., Al-Amry, M. and Al-Rawahy, F. (2007) Compositional and Functional Characteristics of Dates Syrups and Their By-Products. Food Chemistry, 104, 943-947. http://dx.doi.org/10.1016/j.foodchem.2006.12.051

[5] Al-Shoaibi, Z., Al-Mamary, M.A., Al-Habori, M.A., Al-Zubairi, A.S. and Abdelwahab, S.I. (2012) In Vitro Antioxidative and Hepatoprotective Effects of Palm Date Fruits (Phoenix doctylifera). International Journal of Pharmacology, 8, 185-191.

[6] Benmeddour, Z., Mehinagic, E., Meurlay, D.L. and Louaileche, H. (2013) Phenolic Composition and Antioxidant Capacities of Ten Algerian Date (Phoenix dactylifera L.) Cultivars: A Comparative Study. Journal of Functional Foods, 5, 346-354. http://dx.doi.org/10.1016/j.jff.2012.11.005

[7] Soto, G., Luna-Orea, P., Wagga, M.G., Smyth, T.J. and Alvarado, A. (2005) Foliage Residue Decomposition and Nutrient Release in Peach Palm (Bactris gasipaes Kunth) Plantations for Heart-of-Palm Production in Costa Rica. Agronomy Journal, 97, 1396-1402. http://dx.doi.org/10.2134/agronj2004.0250

[8] Tabora, P.C., Balick Jr., M.J., Bovi, M.L.A. and Guerra, M.P. (1993) Hearts of Palm (Bactris euterpe and Others). In: Williams, J.T., Ed., Pulses and Vegetables, Chapman and Hall, London, 193-218.

[9] Pollak, H., Mattos, M. and Uhl, C. (1995) A Profile of Palm Heart Extraction in the Amazon Estuary. Human Ecology, 23, 357-385. http://dx.doi.org/10.1007/BF01190137

[10] Shimizu, M.M., Melo, G.A., Santos, A.B.D., Botcher, A., Casarino, I., Araujo, P., Moura, J.C.M.S. and Mazzafera, P. 
(2011) Enzyme Chatacterization, Isolation and cDNA Cloning of Polyphenol Oxidase in the Hearts of Palm of Three Commercially Important Species. Plant Physiology and Biochemistry, 49, 970-977. http://dx.doi.org/10.1016/j.plaphy.2011.04.006

[11] Movahed, A., Mohammadi, M.M., Akbarzadeh, S., Nabipour, I., Ramezanian, N. and Hajian, N. (2012) The Heart of Date Palm: Its Nutritional and Functional Constituents. Iranian South Medical Journal, 2, 100-105.

[12] AOAC (2005) Official Methods of Analysis. 18th Edition, Association Official Analytical Chemists, Gaitherburg.

[13] Xu, B.J. and Chang, S.K.C. (2007) A Comparative Study on Phenolic Profiles and Antioxidant Activities of Legumes as Affected by Extraction Solvents. Journal of Food Science, 72, S159-S166. http://dx.doi.org/10.1111/j.1750-3841.2006.00260.x

[14] Simas, D.K.N., Vieira, L.D.N., Podesta, R., Vierira, M.A., Rockenbach, I.I., Petkowicz, C.L.O., Medeiros, J.D.D., Francisco, A.D., Amante, E.R. and Ambani, R.D.M.C. (2010) Microstructure, Nutrient Composition and Antioxidant Capacity of King Palm Flour: A New Potential Source of Dietary Fiber. Bioresource Technology, 101, 5701-5707. http://dx.doi.org/10.1016/j.biortech.2010.02.053

[15] Leterme, P., Buldgen, A., Estroda, F. and Landoňo, A.M. (2006) Mineral Content of Tropical Fruits and Unconvential Foods of the Andes and the Rain Forest of Colombia. Food Chemistry, 95, 644-652. http://dx.doi.org/10.1016/j.foodchem.2005.02.003

[16] Mälkki, Y. (2001) Physical Properties of Dietary Fiber as Keys to Physiological Functions. Cereal Foods World, 46, 196-199.

[17] Groff, J.L., Gropper, S.S. and Hunt, S.M. (2002) Macrominerals (Chap. 11), Microminerals (Chap. 12). In: Groff, J.L., Ed., Advance Nutrition and Human Metabolism, 2nd Edition, West Publishing Company, New York, 320.

[18] Kieliszek, M. and Blaźejak, S. (2013) Selenium: Significance and Outlook for Supplementation. Nutrition, 29, 713-718. http://dx.doi.org/10.1016/j.nut.2012.11.012

[19] Vieira, P.A.F., Gontijo, D.C., Assunçäo, D.L.S., Leite, J.P.V., Oliveira, M.G.D.A., Kasuya, M.C.M., et al. (2013) Antioxidant Activities, Total Phenolics and Metal Content in pleurotus ostreatus Mushrooms Enriched with Iron, Zinc or Lithium. LWT, Food Science and Technology, 54, 421-425. http://dx.doi.org/10.1016/j.lwt.2013.06.016

[20] Damodaran, D., Shatty, K.V. and Mohan, B.R. (2013) Effect of Chelaters on Bioaccumulation of Cd (II), Cu (II), Cr (VI), $\mathrm{Ph}$ (II) and Zn (II) in Galerina vittiformis from Soil. International Biodeterioration and Biodegradation, 85, 182188. http://dx.doi.org/10.1016/j.ibiod.2013.05.031

[21] Aldjain, I.M., Al-Whaibi, M.H., Al-Showiman, S.S. and Siddiqui, M.H. (2011) Determination of Heavy Metals in the Fruit of Date Palm Growing at Different Location of Riyadh. Saudi Journal of Biological Sciences, 18, 175-180. http://dx.doi.org/10.1016/j.sjbs.2010.12.001

[22] Al-Farsi, M.A. and Lee, C.Y. (2008) Optimization of Phenolics and Dietary Fiber Extraction from Date Seeds. Food Chemistry, 108, 977-985. http://dx.doi.org/10.1016/j.foodchem.2007.12.009

[23] Heim, K.E., Taglieferro, A.R. and Bobilya, D.J. (2002) Flavonoid Antioxidants: Chemistry, Metabolism and StructureActivity Relationships. The Journal of Nutritional Biochemistry, 13, 572-584. http://dx.doi.org/10.1016/S0955-2863(02)00208-5

[24] Hagerman, A.E., Riedal, K.M., Jones, G.A., Sovik, K.N., Hartzfeld, P.W. and Riechel, T.L. (1998) High Molecular Weight Plant Phenolics (Tannins) as Biological Antioxidants. Journal of Agricultural and Food Chemistry, 46, 18871892. http://dx.doi.org/10.1021/jf970975b

[25] Kang, J., Thakali, K.M., Xie, C., Kondo, M., Tong, Y., Ou, B., Hensen, G., Madina, M.B., Schauss, A.G. and Wu, X. (2012) Bioactivities of Açai (Euterpe oleracea Mart.) Fruit Pulp, Superior to Euterpe oleracea Mart. Food Chemistry, 123, 671-677. http://dx.doi.org/10.1016/j.foodchem.2012.01.048

[26] Biglari, F., Al-Karkhi, A.F.M. and Easa, A.M. (2008) Antioxidant Activity and Phenolic Content of Various Date Palm (Phoenix dactylifera) Fruits from Iran. Food Chemistry, 107, 1636-1641. http://dx.doi.org/10.1016/j.foodchem.2007.10.033

[27] Sultana, B., Anwar, F. and Przybylski, R. (2007) Antioxidant Activity of Phenolic Components Present in Bakers of Azadirachta indica, Terminalia arjuna, Acacia nilotica and Eugenia jambolana Lam. Trees. Food Chemistry, 104, 1106-1114. http://dx.doi.org/10.1016/j.foodchem.2007.01.019

[28] Mansouri, A., Embarek, G., Kokkalou, E. and Kefalas, P. (2005) Phenolic Profile and Antioxidant Activity of the Algerian Ripe Date Palm Fruit (Phoenix dactyfera). Food Chemistry, 89, 411-420. http://dx.doi.org/10.1016/j.foodchem.2004.02.051

[29] Lim, Y.Y., Lim, T.T. and Tee, J.J. (2007) Antioxidant Properties of Several Tropical Fruits: A Comparative Study. Food Chemistry, 103, 1003-1008. http://dx.doi.org/10.1016/j.foodchem.2006.08.038

[30] El-Agbar, Z.A., Shakya, A.K., Khalaf, N.A. and Al-Faroon, M. (2008) Comparative Antioxidant Activity of Some Edible Plant. Turkish Journal of Biology, 32, 193-196. 
Scientific Research Publishing (SCIRP) is one of the largest Open Access journal publishers. It is currently publishing more than 200 open access, online, peer-reviewed journals covering a wide range of academic disciplines. SCIRP serves the worldwide academic communities and contributes to the progress and application of science with its publication.

Other selected journals from SCIRP are listed as below. Submit your manuscript to us via either submit@scirp.org or Online Submission Portal.
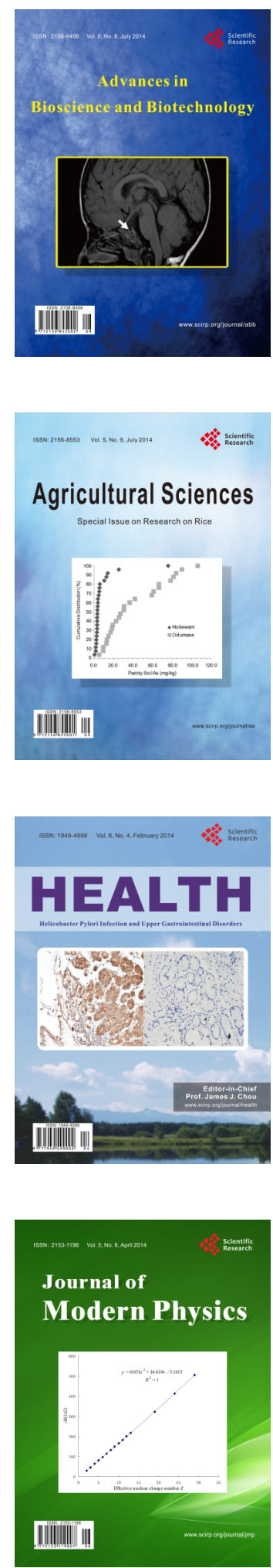
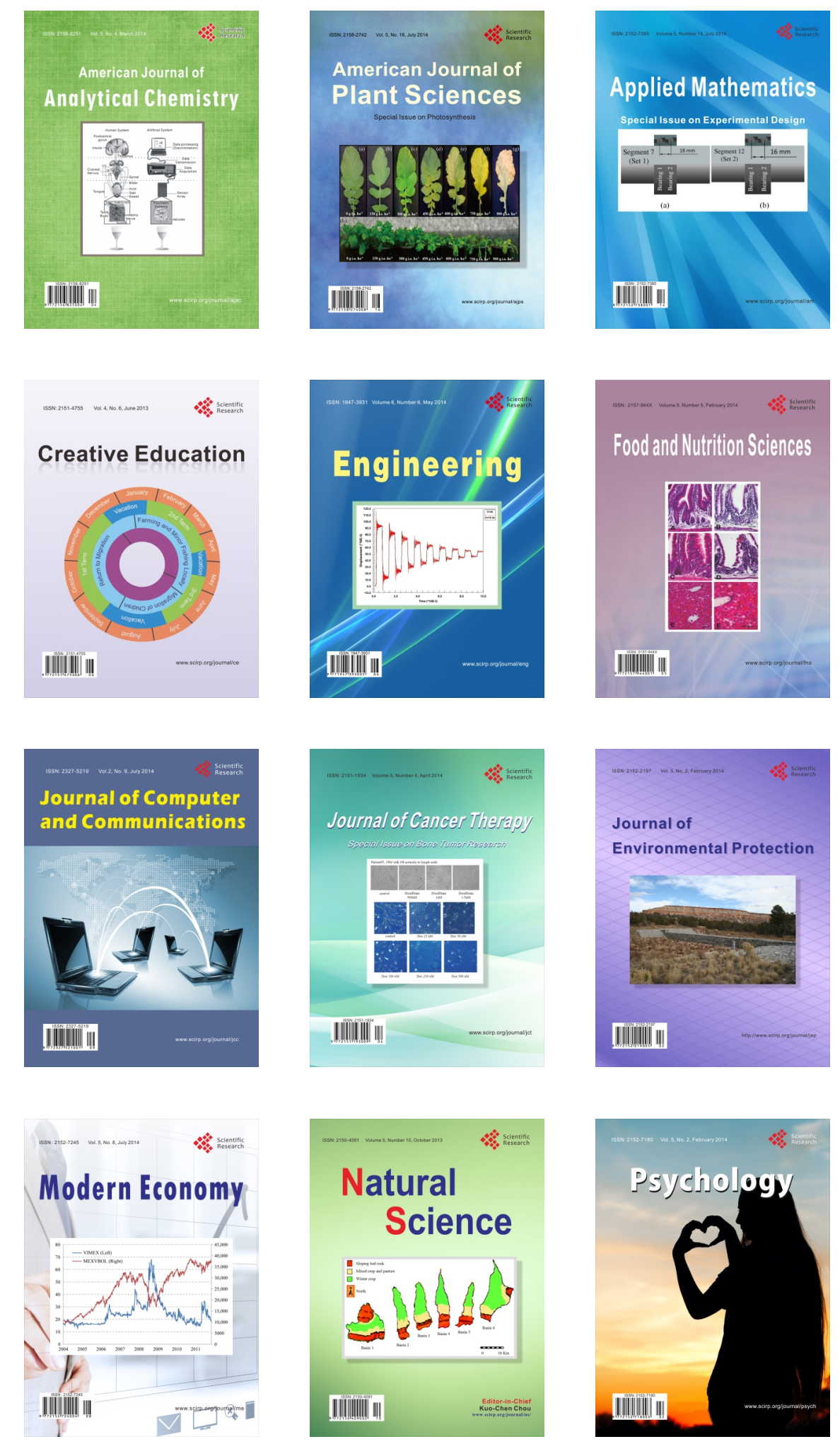